\title{
EFFECT OF MICROWAVE RADIATION ON THE ANTIOXIDANT ACTIVITY OF BLACK CUMIN SEED
}

\author{
Jewel Hossen, Abbas Ali ${ }^{凶}$ \\ Department of Chemistry, Rajshahi University of Engineering and Technology \\ Rajshahi 6204, Bangladesh
}

\begin{abstract}
Background. Black cumin seed contains considerable amounts of bioactive phenolics that have physiological activity and antioxidant potency, which may be boosted by microwave radiation. The core objective of the study was to evaluate the influence of microwave radiation on the antioxidant activity of cumin seed as a function of pretreatment time and extract concentration.

Material and methods. In this study, total flavonoid content (TFC) and antioxidant activity of methanol (CME), 70\% methanol in water (CMW), ethanol (CEE) and 70\% ethanol in water (CEW) extracts of microwaved radiated cumin seed were measured. The antioxidant activity was determined using a Folin-Ciocalteu assay, phosphomolybdenum assay, DPPH radical scavenging activity, $\mathrm{H}_{2} \mathrm{O}_{2}$ scavenging activity, hydroxyl radical scavenging activity and reducing power. To predict antioxidant potency, FTIR spectra of extracts were also recorded.

Results. Microwave pretreatment significantly reduced the TFC with the pretreatment time. Antioxidant activity increased with increasing pretreatment time and extract concentration in all extracts. Aqueous methanolic extract from radiated seeds appeared to display the highest effectiveness. The results from FT-IR of extracts indicating the existence of multiple functional groups were comparable to those obtained from multiple antioxidative assays. The antioxidant effectiveness of the samples was ranked: $\mathrm{CMW}>\mathrm{CEW}>\mathrm{CME}>\mathrm{CEE}$. Conclusions. Both treatment duration and extract concentration were found to be critical factors in determining the overall quality of the product. The present study revealed important information for using black cumin seed in developing food products with high antioxidant potency.
\end{abstract}

Keywords: antioxidant activity, black cumin, microwave pretreatment, scavenging activity

\section{INTRODUCTION}

Black cumin (Nigella sativa L.) seed is widely used as spice and has a unique odor and bitter taste, making it an indispensable ingredient in a variety of dishes (Kiralan, 2012). In the ethno-pharmacology field, due to having considerable quantities of compounds with bioactivities, black cumin seeds are used in traditional medicine as a diuretic, antihypertensive, digestive appetite stimulant, anthelmintic and antibacterial agent (Forouzanfar et al., 2014). In order to retard oxidative deterioration of fatty foods, a number of synthetic antioxidants such as butylated hydroxyanisole (BHA), butylated hydroxytoluene (BHT), and tert-butyl hydroquinone (TBHQ) are widely used in the food industry. This is because they are effective and less expensive than natural antioxidants. But the synthetic antioxidants currently used have been found to exhibit various negative health effects in humans (Saito et al., 2002). Although synthetic antioxidants are used in low 
concentrations, there is a need for antioxidants without side effects, because the complications resulting from the long-term use of these compounds in humans cannot be ignored (Yassari and Yasari, 2013). Hence, the development and utilization of alternative antioxidants from natural source is required. Crude extracts of herbs and spices and other plant materials rich in phenolics are of increasing interest in the food industry, because of their capacities to retard oxidative degradation of lipids. This improves the quality and nutritional value of food. Among herbs and spices, most attention has focused on rosemary as a source of antioxidants. However, black cumin seed is another annual herbaceous plant used as a source of antioxidant (Atta, 2003).

Black cumin is consumed raw or preferably roasted in food items such as bakery products. Whole seeds are dry roasted or fried in oil to give a more intense aroma to some dishes (Kiralan, 2012). Microwave pretreatment has been introduced as an impressive technique which improves antioxidant and functional properties of food components. The advantages of microwave radiation are that it reduces processing time and energy consumption. The energy is transported instantly to the materials, resulting in heat generation throughout the material, and it is likely to produce quick and uniform heat treatment of relatively thick materials (Đurđević et al., 2017). Jan et al. (2019) reported that the antioxidant activity, total phenolic content and reducing power was enhanced by microwave roasting. Ali et al. (2016) stated that antioxidant activity increased with increasing roasting time and extract concentration of groundnut seeds. To date, extensive studies have been conducted on the physico-chemical and antioxidant properties of black cumin seeds without applying any microwave radiation (Kadam et al., 2018; Saxena et al., 2017; Soleimanifar et al., 2019). To the best of our knowledge, no or few studies have been reported on the effect of microwave pretreatment on antioxidative activity of the black cumin seeds, which are the main objective of the present study.

\section{MATERIALS AND METHODS}

\section{Materials}

Fresh black cumin seeds $(2.5 \mathrm{~kg})$ were purchased from a local market in Rajshahi, Bangladesh. The mature and healthy seeds were trimmed, dried in the shade at room temperature and stored at $4^{\circ} \mathrm{C}$ in sealed plastic bags. The various chemicals and reagents used were of analytical grade or better quality. The Folin-Ciocalteu reagent was produced by Merck (Darmstadt, Germany), while 1,1-diphenyl-2-picrylhydrazyl came from Sigma (St. Louis, Mo, USA). All other chemicals and solvents were from Merck (Darmstadt, Germany or Mumbai, India) unless otherwise stated.

\section{Pretreatment and preparation of extract}

The cumin seeds were spread on Pyrex petri dishes (12 $\mathrm{cm}$ diameter) placed on the turntable plate of a domestic microwave oven (MS 3042G, LG, China). The samples were microwave radiated at a constant frequency of $2450 \mathrm{MHz}$ and a power of $580 \mathrm{~W}$ for 1, 2 and $3 \mathrm{~min}$. The selection of these microwave conditions was based on preliminary trials in which it was determined that at a longer time and higher microwave power the seeds started to produce smoke and burn. A seed sample with no microwave treatment was utilized as a control. After treatment, the seeds were allowed to cool to ambient temperature. The raw or treated seeds were ground into a fine powder. The moisture content was determined by AOAC (2005) official method 930.15. Two hundred grams of each ground material were first defatted by mechanical pressing at room temperature. The residual oil from the defatted seeds left after pressing was removed with $n$-hexane $(1: 8 \mathrm{w} / \mathrm{v})$ by agitation using a magnetic stirrer at room temperature for $2 \mathrm{~h}$. The defatted seeds obtained after filtration was dried overnight under a hood until all traces of n-hexane were removed. For antioxidative evaluation, the extraction was carried out separately with methanol (CME), 70\% methanol in water (CMW), ethanol (CEE) and 70\% ethanol in water (CEW) from the defatted seeds using a magnetic stirrer following the procedure described above. After filtration, the filtrates were concentrated in a rotary evaporator at $45^{\circ} \mathrm{C}$ under reduced pressure and stored in the dark at $-16^{\circ} \mathrm{C}$.

\section{Total flavonoid content (TFC) assay}

The TFC was estimated following the method of $\mathrm{Wu}$ and $\mathrm{Ng}$ (2008). $0.5 \mathrm{~mL}$ of sample was mixed with $2.2 \mathrm{~mL}$ of deionized water, $0.15 \mathrm{~mL}$ of $5 \%$ sodium nitrite and $0.15 \mathrm{~mL}$ of $10 \%$ aluminium chloride. The whole mixture was then kept to react for $6 \mathrm{~min}$ at room temperature, followed by the addition of $2 \mathrm{~mL}$ of $4 \%$ 
sodium hydroxide. After $15 \mathrm{~min}$, the absorbance of the mixture was recorded at $510 \mathrm{~nm}$. The TFC was expressed as a catechin equivalent (CE) and the results were presented as $\mathrm{mg} \mathrm{CE} / \mathrm{g}$ extract.

\section{Antioxidant activity assays}

Total antioxidant capacity by Folin-Ciocalteu assay (TACF). The total antioxidant capacity was determined spectrophotometrically using a Folin-Ciocalteu (F-C) reagent according to the method developed by Škerget et al. (2005). The sample $(0.5 \mathrm{~mL})$ was added to a mixture of $2.5 \mathrm{~mL}$ of $\mathrm{F}-\mathrm{C}$ reagent (diluted 10 times with distilled water) and $2 \mathrm{~mL}$ of $\mathrm{Na}_{2} \mathrm{CO}_{3}(75 \mathrm{~g} / \mathrm{L})$. The sample solution was incubated for $30 \mathrm{~min}$ at $50^{\circ} \mathrm{C}$ in the dark and then cooled. Distilled water $(0.5 \mathrm{~mL})$ was used as a control. The absorbance was recorded at $760 \mathrm{~nm}$ using a spectrophotometer. The TACF was expressed as a gallic acid equivalent (GAE) in $\mathrm{mg}$ $\mathrm{GAE} / \mathrm{g}$ extract.

Total antioxidant capacity by phosphomolybdenum assay (TACP). The method developed by Adom et al. (2005) was followed to determine the total antioxidant capacity. In this method, a mixture of $0.3 \mathrm{~mL}$ sample and $3 \mathrm{~mL}$ of reagent $(0.6 \mathrm{M}$ sulphuric acid, $28 \mathrm{mM}$ sodium phosphate, and $4 \mathrm{mM}$ ammonium molybdate) was poured into a test tube; the mixture was then incubated at $95^{\circ} \mathrm{C}$ for $90 \mathrm{~min}$. After cooling to $25^{\circ} \mathrm{C}$, the absorbance was read at $695 \mathrm{~nm}$ against a blank on the spectrophotometer. The TACP was considered as a ascorbic acid equivalent (AAE). The result was expressed as mg AAE/g extract.

1,1-Diphenyl-2-picrylhydrazyl (DPPH) assay. The radical scavenging activity was determined following the method developed by Negro et al. (2003). $2 \mathrm{~mL}$ of freshly prepared $0.2 \mathrm{mM}$ DPPH methanolic solution was added to $2 \mathrm{~mL}$ of the samples dissolved in the extracting solvent at different concentrations. The reaction mixture was shaken and incubated in the dark at room temperature for $30 \mathrm{~min}$. The absorbance was recorded at $517 \mathrm{~nm}$ against the blank control. The control solution contained equivalent $70 \%$ methanol instead of the sample solution. The inhibition of the DPPH radical by the sample was calculated according to the following formula:

$$
\begin{aligned}
& \text { DPPH radical scavenging activity, } \%= \\
& \quad=\left[\left(A_{\text {control }}-A_{\text {sample }}\right) / A_{\text {control }}\right] \times 100
\end{aligned}
$$

$\mathrm{H}_{2} \mathrm{O}_{2}$ scavenging activity. The ability to scavenge hydrogen peroxide was evaluated according to Ruch et al.'s method (1989). A solution of $\mathrm{H}_{2} \mathrm{O}_{2}(40 \mathrm{mM})$ was prepared in a phosphate buffer solution $(\mathrm{pH}=$ $7.40,0.2 \mathrm{~mol} / \mathrm{L}$ ). The extracts at different concentrations were mixed with a hydrogen peroxide solution $(0.6 \mathrm{ml})$. After $15 \mathrm{~min}$ incubation, the absorbance at $230 \mathrm{~nm}$ was recorded against a blank solution containing a phosphate buffer without hydrogen peroxide. The scavenging activity was calculated using the following formula:

$$
\% \text { inhibition }=\left[\left(A_{0}-A_{1}\right) / A_{0}\right] \times 100
$$

where:

$A_{0}$ - the absorbance of the control,

$A_{1}$ - absorbance in the presence of the extract.

Hydroxyl radical scavenging activity. The hydroxyl radical scavenging activity was investigated by the method of Smirnoff and Cumbes (1989) with a slight modification (Guo et al., 2011). The following reagents were poured into a reaction tube in the order: $0.3 \mathrm{ml}$ of $20 \mathrm{mM}$ sodium salicylate, $1.0 \mathrm{ml}$ of $1.5 \mathrm{mM} \mathrm{FeSO}_{4}$, $1.0 \mathrm{ml}$ of various concentrations of sample solution, $0.7 \mathrm{ml}$ of $6 \mathrm{mM} \mathrm{H}_{2} \mathrm{O}_{2}$. They were mixed immediately, and then the reaction tubes were put in a water bath at $37^{\circ} \mathrm{C}$ for $1 \mathrm{~h}$. The absorbance of the mixture was recorded at $510 \mathrm{~nm}$ against a blank. The hydroxyl radical scavenging ability was calculated as follows:

Hydroxyl radical scavenging activity, $\%=$

$$
=\left[\left(A_{0}-A_{1}\right) / A_{0}\right] \times 100
$$

where:

$A_{0}$ - the absorbance of the control,

$A_{1}$-absorbance in the presence of the sample solution.

Reducing power. The reducing power of the samples was determined according to the method developed by Atmani et al. (2009). One millilitre of the sample with different concentrations in $2.0 \mathrm{~mL}$ of phosphate buffer (0.2 M, pH 6.6) was added to $2.5 \mathrm{~mL}$ of $1 \%$ potassium ferrycyanide. The mixture was incubated at $50^{\circ} \mathrm{C}$ for $20 \mathrm{~min} ; 2.5 \mathrm{~mL}$ of $10 \%$ trichloroacetic acid 
added to the mixture. A portion of the solution (2.5 $\mathrm{mL}$ ) was added to $2.5 \mathrm{~mL}$ of distilled water and $0.5 \mathrm{~mL}$ of $0.1 \%$ ferric chloride. The absorbance of the solution was measured at $700 \mathrm{~nm}$ at a reaction time of $30 \mathrm{~min}$. The increase in the absorbance of the reaction mixture indicated the reducing power of the sample.

FT-IR spectroscopy. The IR spectra of the solvent extracts was measured by FT-IR spectrophotometer (IR Affinity-1S, Shimadzu Corporation, Kyoto, Japan) equipped with a high sensitivity pyroelectric detector (deuterated L-alanine doped triglycine sulphate) using sodium chloride cell. The spectra were obtained in the range of $4000-700 \mathrm{~cm}^{-1}$ with a spectral resolution of $4 \mathrm{~cm}^{-1}$ and periodical scans of 16 .

Statistical analysis. The data were depicted as the mean and standard deviation (SD) of triplicate determinations and subjected to one-way analysis of variance (ANOVA). Mean values were compared at $p<0.05$ significant level by Duncan's multiple range test using IBM SPSS 22 statistics.

\section{RESULTS AND DISCUSSION}

The microwave pretreatment reduced the moisture content from $5.5 \%$ to $4.10,2.60$ and $1.10 \%$ for 1,2 and 3 min, respectively. The results are in agreement with the findings reported by Ali et al. (2017) for pumpkin seeds. As shown in Table 1, microwave radiation had a remarkable effect on the yield of the extract in all the samples; with increasing pre-treatment times, the percentage of the yield increased. The percentage yields of crude extracts CMW, CEW, CME, and CEE were $5.89,5.84,5.74$ and $4.65 \%$ for raw samples, whereas $6.93,6.86,6.65$ and $5.42 \%$ computed for 3 min microwaved samples, respectively. The pretreatment condition employed in this study may cause damage to the cell membranes, leading to the high extractability. However, the amount of crude extract in the solvent systems containing water was slightly higher compared to pure solvent.

\section{Total flavonoid contents (TFC)}

Microwave pretreatment significantly $(p<0.05)$ reduced the TFC in cumin seeds (Table 1). Total flavonoid contents of untreated seeds ranged from $0.42 \mathrm{mg} \mathrm{CE} / \mathrm{g}$
(CEE) to $0.82 \mathrm{mg} \mathrm{CE} / \mathrm{g}$ (CMW) compared with $3 \mathrm{~min}$ treated seed values that ranged from 0.34 (CEE) to $0.57 \mathrm{mg} \mathrm{CE} / \mathrm{g}(\mathrm{CMW})$. These reductions could be attributed to flavonoid breakdown during the heating process. These results are in good agreement with those indicated by Ali et al. (2016), who reported that the flavonoid content decreased as a result of the roasting process.

\section{Antioxidant activity assays}

As shown in Table 1, the total antioxidant capacity as determined by an F-C assay of the four types of extracts decreased in the following order: CMW > $\mathrm{CEW}>\mathrm{CME}>\mathrm{CEE}$ (Table 1). At 3 min treatment, the samples showed TACF of $20.77 \mathrm{mg} \mathrm{GAE} / \mathrm{g}$ or more: CMW (25.76 mg GAE/g) > CEW (22.62 mg $\mathrm{GAE} / \mathrm{g})>\mathrm{CME}(22.47 \mathrm{mg} \mathrm{GAE} / \mathrm{g})>\mathrm{CEE}(20.77 \mathrm{mg}$ $\mathrm{GAE} / \mathrm{g}$ ). The antioxidant capacity increased steadily with the increased time of treatment. A similar trend was reported by Ali et al. (2016) for microwave roasted groundnut extracts. Several studies also reported that heat treatment is effective in increasing the total antioxidant capacity in different food materials such as fenugreek seeds (Pandey and Awasthi, 2015). The methanolic extracts contained a higher amount of TFC compared to ethanolic extracts. In addition, higher F-C-reducing capacity was found in aqueous extracts than in pure solvent extracts of methanol or ethanol. The total antioxidant capacity of solvent extracts was also evaluated routinely by using the phosphomolybdenum method. Total antioxidant activities from the phosphomolybdenum assay of different extracts gradually increased during pretreatment, reaching an apparent maximum within $3 \mathrm{~min}$ (Table 1). The TACP (in $\mathrm{mg} \mathrm{AAE} / \mathrm{g}$ ) in the samples CMW, CEW, CME, and CEE increased significantly from $20.26,23.83,29.11$ and 34.97 in raw seeds, and to $31.69,35.83,37.97$ and 46.91 in microwaved seeds at $3 \mathrm{~min}$, respectively. Among the four solvents, methanol was the most suitable solvent in terms of total antioxidant capacity measured by the phosphomolybdenum method. Increased antioxidant activity measured by the phosphomolybdenum method of methanolic extract during the roasting of groundnuts was reported previously (Ali et al., 2016). The antioxidant activity in a DPPH scavenging assay was measured by the decrease in absorbance as the DPPH radical received an electron or hydrogen radical from 
Hossen, J., Ali, A. (2019). Effect of microwave radiation on the antioxidant activity of black cumin seed. Acta Sci. Pol. Technol. Aliment., 18(3), 257-268. http://dx.doi.org/10.17306/J.AFS.2019.0671

Table 1. Effect of microwave pretreatment on extraction yield, TFC, TACF and TACP of solvent extracts of black cumin seed

\begin{tabular}{lccccc}
\hline \multirow{2}{*}{ Parameter } & $\begin{array}{c}\text { Pretreatment time } \\
\text { min }\end{array}$ & \multicolumn{4}{c}{ Solvent extract } \\
\cline { 3 - 6 } Yield, \% & 0 & $4.65 \pm 0.12^{\mathrm{aA}}$ & $5.74 \pm 0.10^{\mathrm{aB}}$ & $5.84 \pm 0.11^{\mathrm{aB}}$ & $5.89 \pm 0.10^{\mathrm{aB}}$ \\
& 1 & $4.76 \pm 0.09^{\mathrm{abA}}$ & $5.87 \pm 0.11^{\mathrm{aB}}$ & $5.98 \pm 0.11^{\mathrm{aB}}$ & $6.10 \pm 0.10^{\mathrm{aB}}$ \\
& 2 & $5.02 \pm 0.12^{\mathrm{abA}}$ & $6.14 \pm 0.11^{\mathrm{bB}}$ & $6.31 \pm 0.11^{\mathrm{bBC}}$ & $6.42 \pm 0.09^{\mathrm{bC}}$ \\
TFC, & 3 & $5.42 \pm 0.08^{\mathrm{bA}}$ & $6.65 \pm 0.12^{\mathrm{cB}}$ & $6.86 \pm 0.09^{\mathrm{cBC}}$ & $6.93 \pm 0.10^{\mathrm{cC}}$ \\
CE mg/g extract & 0 & $0.42 \pm 0.03^{\mathrm{aA}}$ & $0.74 \pm 0.03^{\mathrm{aC}}$ & $0.56 \pm 0.03^{\mathrm{aA}}$ & $0.82 \pm 0.05^{\mathrm{aD}}$ \\
& 1 & $0.40 \pm 0.04^{\mathrm{abA}}$ & $0.63 \pm 0.05^{\mathrm{bA}}$ & $0.47 \pm 0.04^{\mathrm{bB}}$ & $0.70 \pm 0.05^{\mathrm{bB}}$ \\
TACF, GAE & 2 & $0.38 \pm 0.05^{\mathrm{abA}}$ & $0.53 \pm 0.05^{\mathrm{cB}}$ & $0.39 \pm 0.04^{\mathrm{cA}}$ & $0.64 \pm 0.04^{\mathrm{bcC}}$ \\
mg/g extract & 3 & $0.34 \pm 0.03^{\mathrm{bA}}$ & $0.43 \pm 0.04^{\mathrm{dB}}$ & $0.34 \pm 0.03^{\mathrm{cA}}$ & $0.57 \pm 0.05^{\mathrm{cC}}$ \\
& 0 & $13.50 \pm 0.52^{\mathrm{aA}}$ & $16.05 \pm 0.51^{\mathrm{aB}}$ & $17.64 \pm 0.79^{\mathrm{aC}}$ & $19.43 \pm 0.42^{\mathrm{aD}}$ \\
& 1 & $14.92 \pm 0.67^{\mathrm{bA}}$ & $17.14 \pm 0.79^{\mathrm{aB}}$ & $19.79 \pm 0.55^{\mathrm{bC}}$ & $22.09 \pm 0.78^{\mathrm{bD}}$ \\
TACP, AAE & 2 & $17.87 \pm 0.56^{\mathrm{cA}}$ & $19.20 \pm 0.63^{\mathrm{bB}}$ & $20.42 \pm 0.38^{\mathrm{bC}}$ & $23.94 \pm 0.68^{\mathrm{cD}}$ \\
mg/g extract & 3 & $20.77 \pm 0.44^{\mathrm{dA}}$ & $22.47 \pm 0.44^{\mathrm{cB}}$ & $22.62 \pm 0.51^{\mathrm{cB}}$ & $25.76 \pm 0.73^{\mathrm{dC}}$ \\
& 0 & $20.26 \pm 0.40^{\mathrm{aA}}$ & $23.83 \pm 0.63^{\mathrm{aB}}$ & $29.11 \pm 0.57^{\mathrm{aC}}$ & $34.97 \pm 0.64^{\mathrm{aD}}$ \\
& 1 & $25.40 \pm 0.67^{\mathrm{bA}}$ & $26.54 \pm 0.65^{\mathrm{bA}}$ & $33.40 \pm 0.72^{\mathrm{bB}}$ & $36.54 \pm 0.52^{\mathrm{bC}}$ \\
& 2 & $28.69 \pm 0.48^{\mathrm{cA}}$ & $29.54 \pm 0.62^{\mathrm{cB}}$ & $35.11 \pm 0.36^{\mathrm{cC}}$ & $40.37 \pm 0.25^{\mathrm{cD}}$
\end{tabular}

The results are expressed as means \pm standard deviations of triplicate determinations. Values with different letters (lower case) within a column for each parameter were significantly different $(p<0.05)$. Values with different letters (uppercase) within a row for each parameter were significantly different $(p<0.05)$.

$\mathrm{CME}$ - methanol extract, CMW - 70\% methanol in water extract, CEE - ethanol extract, CEW - 70\% ethanol in water extract, TFC - total flavonoid content, TACF - total antioxidant capacity by Folin-Ciocalteu assay, TACP - total antioxidant capacity by phosphomolybdenum assay.

an antioxidant compound to become a stable diamagnetic molecule (Juntachote and Berghofer, 2005). The present pretreatment process caused a clear increase in antioxidant activity that was measured by DPPH (Table 2). At $31.25 \mu \mathrm{g} / \mathrm{mL}$, the extracts CMW, CEW, CME, and CEE from untreated seeds showed $42.62,40.32,38.21$, and $35.25 \%$ of DPPH scavenging activity, respectively, whereas the same solvent extracts from samples treated for $3 \mathrm{~min}$ showed $50.77,47.22,46.64$, and $44.14 \%$, respectively. These increases could be due to the formation of Maillard products such as HMF (5-hydroxymethyl-2-furaldehyde), which resulted in high antioxidant activity. In addition, the samples showed dose-dependent DPPH radical-scavenging activities and the scavenging effect increased as the concentration of the extract increased. The highest antioxidant activity was exhibited by the samples treated at $3 \mathrm{~min}$ and $500 \mu \mathrm{g} / \mathrm{mL}$. The variation in DPPH scavenging activity was statistically significant between raw and treated samples. The DPPH radical scavenging activity of the samples is ranked in the following order: $\mathrm{CMW}>\mathrm{CEW}>$ CME $>$ CEE in both native as well as treated samples. In general, the aqueous methanol extracts exhibited higher scavenging activities, which may be due to the greater release of antioxidants.

As shown in Table 3, the $\mathrm{H}_{2} \mathrm{O}_{2}$ scavenging activity increased with an increase in concentration and treatment times. The scavenging activity at $31.25 \mu \mathrm{g} / \mathrm{mL}$ ranged from $28.71,22.07,21.87$ and $18.97 \%$ in untreated 
Hossen, J., Ali, A. (2019). Effect of microwave radiation on the antioxidant activity of black cumin seed. Acta Sci. Pol. Technol. Aliment., 18(3), 257-268. http://dx.doi.org/10.17306/J.AFS.2019.0671

Table 2. Effect of microwave pretreatment on DPPH radical scavenging activity of solvent extracts of black cumin seed

\begin{tabular}{|c|c|c|c|c|c|c|}
\hline \multirow{2}{*}{$\begin{array}{c}\text { Solvent } \\
\text { extract }\end{array}$} & \multirow{2}{*}{$\begin{array}{l}\text { Pretreatment } \\
\text { time, min }\end{array}$} & \multicolumn{5}{|c|}{ Extract concentration, $\mu \mathrm{g} / \mathrm{mL}$} \\
\hline & & 31.25 & 62.5 & 125 & 250 & 500 \\
\hline \multirow[t]{4}{*}{ CMW } & 0 & $42.62 \pm 1.41^{\mathrm{aA}}$ & $48.24 \pm 0.70^{\mathrm{aB}}$ & $55.76 \pm 1.52^{\mathrm{aC}}$ & $65.08 \pm 0.83^{\mathrm{aD}}$ & $70.51 \pm 0.66^{\mathrm{aE}}$ \\
\hline & 1 & $44.13 \pm 0.91^{\mathrm{aA}}$ & $52.32 \pm 1.00^{\mathrm{bB}}$ & $59.85 \pm 1.20^{\mathrm{bC}}$ & $67.71 \pm 1.35^{\mathrm{bD}}$ & $73.72 \pm 1.26^{\mathrm{bE}}$ \\
\hline & 2 & $47.91 \pm 1.05^{\mathrm{bA}}$ & $55.92 \pm 1.38^{\mathrm{cB}}$ & $63.57 \pm 1.22^{\mathrm{cC}}$ & $70.46 \pm 0.78^{\mathrm{cD}}$ & $78.28 \pm 1.07^{\mathrm{cE}}$ \\
\hline & 3 & $50.77 \pm 1.09^{\mathrm{cA}}$ & $59.21 \pm 0.56^{\mathrm{dB}}$ & $67.29 \pm 0.91^{\mathrm{dC}}$ & $74.22 \pm 0.53^{\mathrm{dD}}$ & $82.72 \pm 1.33^{\mathrm{dE}}$ \\
\hline \multirow[t]{4}{*}{ CEW } & 0 & $40.32 \pm 1.06^{\mathrm{aA}}$ & $46.24 \pm 0.67^{\mathrm{aB}}$ & $51.28 \pm 1.22^{\mathrm{aC}}$ & $55.92 \pm 1.27^{\mathrm{aD}}$ & $64.45 \pm 1.22^{\mathrm{aE}}$ \\
\hline & 1 & $42.12 \pm 0.76^{\mathrm{aA}}$ & $49.11 \pm 0.89^{\text {bB }}$ & $54.94 \pm 1.07^{\mathrm{bC}}$ & $59.24 \pm 0.37^{\mathrm{bD}}$ & $67.21 \pm 0.86^{\mathrm{bE}}$ \\
\hline & 2 & $44.47 \pm 1.26^{\mathrm{bA}}$ & $51.22 \pm 0.89^{\mathrm{cB}}$ & $57.94 \pm 1.25^{\mathrm{cC}}$ & $63.37 \pm 0.84^{\mathrm{cD}}$ & $69.98 \pm 1.33^{\mathrm{cE}}$ \\
\hline & 3 & $47.22 \pm 1.10^{\mathrm{cA}}$ & $54.12 \pm 0.81^{\mathrm{dB}}$ & $61.25 \pm 0.81^{\mathrm{dC}}$ & $67.99 \pm 1.23^{\mathrm{dD}}$ & $74.37 \pm 1.15^{\mathrm{dE}}$ \\
\hline \multirow[t]{4}{*}{ CME } & 0 & $38.21 \pm 0.96^{\mathrm{aA}}$ & $43.32 \pm 0.97^{\mathrm{aB}}$ & $50.57 \pm 0.89^{\mathrm{aC}}$ & $54.23 \pm 0.58^{\mathrm{aD}}$ & $63.12 \pm 0.71^{\mathrm{aE}}$ \\
\hline & 1 & $41.45 \pm 1.04^{\mathrm{bA}}$ & $46.26 \pm 0.90^{\mathrm{bB}}$ & $53.02 \pm 0.67^{\mathrm{bC}}$ & $57.33 \pm 0.75^{\mathrm{bD}}$ & $66.27 \pm 0.74^{\mathrm{bE}}$ \\
\hline & 2 & $43.54 \pm 1.16^{\mathrm{cA}}$ & $49.21 \pm 0.89^{\mathrm{cB}}$ & $56.98 \pm 1.11^{\mathrm{cC}}$ & $62.85 \pm 1.50^{\mathrm{cD}}$ & $68.21 \pm 0.94^{\mathrm{cE}}$ \\
\hline & 3 & $46.64 \pm 0.99^{\mathrm{dA}}$ & $52.33 \pm 0.79^{\mathrm{dB}}$ & $60.33 \pm 0.96^{\mathrm{dC}}$ & $66.6 \pm 0.75^{\mathrm{dD}}$ & $73.53 \pm 1.05^{\mathrm{dE}}$ \\
\hline \multirow[t]{4}{*}{ CEE } & 0 & $35.25 \pm 0.70^{\mathrm{aA}}$ & $40.32 \pm 1.06^{\mathrm{aB}}$ & $46.54 \pm 0.96^{\mathrm{aC}}$ & $50.45 \pm 0.77^{\mathrm{aD}}$ & $53.18 \pm 0.85^{\mathrm{aE}}$ \\
\hline & 1 & $38.65 \pm 0.77^{\mathrm{bA}}$ & $43.36 \pm 0.98^{\mathrm{bB}}$ & $49.85 \pm 1.03^{\mathrm{bC}}$ & $53.46 \pm 0.94^{\mathrm{bD}}$ & $55.07 \pm 0.83^{\mathrm{bD}}$ \\
\hline & 2 & $41.23 \pm 0.96^{\mathrm{cA}}$ & $46.87 \pm 1.33^{\mathrm{cB}}$ & $52.67 \pm 0.99^{\mathrm{cC}}$ & $57.03 \pm 0.92^{\mathrm{cD}}$ & $58.78 \pm 1.13^{\mathrm{cD}}$ \\
\hline & 3 & $44.14 \pm 0.73^{\mathrm{dA}}$ & $50.41 \pm 1.03^{\mathrm{dB}}$ & $55.23 \pm 0.87^{\mathrm{dC}}$ & $59.53 \pm 0.96^{\mathrm{dD}}$ & $62.50 \pm 0.92^{\mathrm{dE}}$ \\
\hline
\end{tabular}

The results are expressed as means \pm standard deviations of triplicate determinations. Values with different letters (lower case) within a column for each solvent extract were significantly different $(p<0.05)$. Values with different letters (uppercase) within a row for each solvent extract were significantly different $(p<0.05)$.

$\mathrm{CME}$ - methanol extract, $\mathrm{CMW}-70 \%$ methanol in water extract, $\mathrm{CEE}$ - ethanol extract, $\mathrm{CEW}-70 \%$ ethanol in water extract.

to $39.89,35.93,30.45$ and $25.07 \%$ in 3 min-treated samples of extracts CMW, CEW, CME, and CEE, respectively. However, the aqueous methanolic extract displayed the highest activity at all concentrations and treatment times compared to the rest of the solvent extracts. Baba et al. (2016) also reported that roasting treatment increased $\mathrm{H}_{2} \mathrm{O}_{2}$ scavenging activity in barley. Hydroxyl radicals are short-lived, most damaging radicals within the body formed from superoxide radicals and hydrogen peroxide which oxidize biological macromolecules including lipids, proteins and nucleic acids (Imlay and Linn, 1988). Table 4 shows the scavenging ability measured as hydroxyl radical scavenging of cumin seed extracts on hydroxyl radicals. The scavenging activity increased with increasing treatment time and concentration of extract. During the microwave processing, the activities measured at 31.25 $\mu \mathrm{g} / \mathrm{mL}$ for example, increased from 25.59 to $40.31 \%$
(CMW), 23.21 to $33.22 \%$ (CEW), 15.87 to $26.37 \%$ (CME), and 13.27 to $25.18 \%$ (CEE). However, the scavenging power in both raw and treated samples increased in the following solvent order: $\mathrm{CMW}>\mathrm{CEW}$ $>\mathrm{CME}>\mathrm{CEE}$. The higher value in hydroxyl radical scavenging activity of groundnut in the roasted sample than in the raw was reported earlier by Ali et al. (2016). All the extracts exhibited potent or moderate activity in a dose-dependent manner. The results suggest that the extracts display a scavenging effect on hydroxyl radical generation that could help to protect proteins, DNA, polyunsaturated fatty acids in membranes, and almost any biological molecule from free radical attack (Sasipriya and Siddhuraju, 2012). The reducing power of an antioxidant compound is associated with the presence of reductones. Furthermore, the antioxidant capacity of reductones is based on the breaking of the free radical chain reaction by donating a hydrogen 
Hossen, J., Ali, A. (2019). Effect of microwave radiation on the antioxidant activity of black cumin seed. Acta Sci. Pol. Technol. Aliment., 18(3), 257-268. http://dx.doi.org/10.17306/J.AFS.2019.0671

Table 3. Effect of microwave pretreatment on hydrogen peroxide scavenging activity of solvent extracts of black cumin seed

\begin{tabular}{|c|c|c|c|c|c|c|}
\hline \multirow{2}{*}{$\begin{array}{l}\text { Solvent } \\
\text { extract }\end{array}$} & \multirow{2}{*}{$\begin{array}{l}\text { Pretreatment } \\
\text { time, min }\end{array}$} & \multicolumn{5}{|c|}{ Extract concentration, $\mu \mathrm{g} / \mathrm{mL}$} \\
\hline & & 31.25 & 62.5 & 125 & 250 & 500 \\
\hline \multirow[t]{4}{*}{ CMW } & 0 & $28.71 \pm 1.60^{\mathrm{aA}}$ & $34.57 \pm 1.19^{\mathrm{aB}}$ & $37.30 \pm 1.05^{\mathrm{aC}}$ & $39.45 \pm 1.09^{\mathrm{aC}}$ & $42.38 \pm 1.05^{\mathrm{aD}}$ \\
\hline & 1 & $33.37 \pm 1.02^{\mathrm{bA}}$ & $37.91 \pm 1.06^{\mathrm{bB}}$ & $40.47 \pm 0.96^{\mathrm{bC}}$ & $43.84 \pm 1.08^{\mathrm{bD}}$ & $46.75 \pm 1.13^{\mathrm{bE}}$ \\
\hline & 2 & $36.69 \pm 1.04^{\mathrm{cA}}$ & $40.42 \pm 0.87^{\mathrm{cB}}$ & $42.60 \pm 1.01^{\mathrm{cC}}$ & $45.55 \pm 0.90^{\mathrm{bD}}$ & $49.53 \pm 1.11^{\mathrm{cE}}$ \\
\hline & 3 & $39.89 \pm 1.31^{\mathrm{dA}}$ & $43.25 \pm 1.08^{\mathrm{dB}}$ & $47.79 \pm 1.41^{\mathrm{dC}}$ & $49.94 \pm 1.12^{\mathrm{cC}}$ & $53.70 \pm 1.04^{\mathrm{dD}}$ \\
\hline \multirow[t]{4}{*}{ CEW } & 0 & $22.07 \pm 0.84^{\mathrm{aA}}$ & $26.20 \pm 0.48^{\mathrm{aB}}$ & $28.71 \pm 1.06^{\mathrm{aC}}$ & $30.85 \pm 1.27^{\mathrm{aD}}$ & $35.54 \pm 1.02^{\mathrm{aE}}$ \\
\hline & 1 & $28.71 \pm 0.97^{\mathrm{bA}}$ & $31.44 \pm 1.18^{\mathrm{bB}}$ & $33.39 \pm 0.82^{\mathrm{bC}}$ & $35.15 \pm 0.88^{\mathrm{bD}}$ & $37.30 \pm 0.88^{\mathrm{bE}}$ \\
\hline & 2 & $31.25 \pm 0.91^{\mathrm{cA}}$ & $33.39 \pm 1.06^{\mathrm{cB}}$ & $34.96 \pm 1.09^{\mathrm{bB}}$ & $37.30 \pm 0.79^{\mathrm{cc}}$ & $39.06 \pm 0.84^{\mathrm{cD}}$ \\
\hline & 3 & $35.93 \pm 1.04^{\mathrm{dA}}$ & $37.69 \pm 1.15^{\mathrm{dB}}$ & $38.47 \pm 0.99^{\mathrm{cB}}$ & $39.25 \pm 0.94^{\mathrm{dB}}$ & $41.02 \pm 0.67^{\mathrm{dC}}$ \\
\hline \multirow[t]{4}{*}{ CME } & 0 & $21.87 \pm 1.75^{\mathrm{aA}}$ & $23.43 \pm 1.21^{\mathrm{aAB}}$ & $25.00 \pm 0.79^{\mathrm{aB}}$ & $27.53 \pm 0.96^{\mathrm{aC}}$ & $32.61 \pm 1.34^{\mathrm{aD}}$ \\
\hline & 1 & $22.85 \pm 0.82^{\mathrm{aA}}$ & $25.82 \pm 1.50^{\mathrm{bB}}$ & $29.68 \pm 1.17^{\mathrm{bC}}$ & $31.59 \pm 1.13^{\mathrm{bC}}$ & $35.35 \pm 0.80^{\mathrm{bD}}$ \\
\hline & 2 & $26.17 \pm 0.96^{\mathrm{bA}}$ & $29.88 \pm 1.21^{\mathrm{cB}}$ & $31.64 \pm 1.38^{\mathrm{bB}}$ & $33.78 \pm 1.26^{\mathrm{cC}}$ & $36.52 \pm 0.95^{\mathrm{bcD}}$ \\
\hline & 3 & $30.45 \pm 1.13^{\mathrm{cA}}$ & $34.76 \pm 0.90^{\mathrm{dB}}$ & $35.74 \pm 1.12^{\mathrm{cB}}$ & $36.52 \pm 1.24^{\mathrm{dBC}}$ & $38.47 \pm 1.23^{\mathrm{cC}}$ \\
\hline \multirow[t]{4}{*}{ CEE } & 0 & $18.97 \pm 0.30^{\mathrm{aA}}$ & $20.95 \pm 1.07^{\mathrm{aB}}$ & $22.71 \pm 0.87^{\mathrm{aC}}$ & $25.44 \pm 0.93^{\mathrm{aD}}$ & $29.03 \pm 0.82^{\mathrm{aE}}$ \\
\hline & 1 & $20.88 \pm 1.20^{\mathrm{bA}}$ & $22.42 \pm 1.17^{\mathrm{aA}}$ & $26.20 \pm 0.88^{\mathrm{bB}}$ & $30.57 \pm 0.92^{\mathrm{bC}}$ & $32.15 \pm 0.93^{\mathrm{bC}}$ \\
\hline & 2 & $23.85 \pm 1.07^{\mathrm{cA}}$ & $27.83 \pm 0.89^{\mathrm{bB}}$ & $31.78 \pm 0.93^{\mathrm{cC}}$ & $33.74 \pm 0.95^{\mathrm{cD}}$ & $34.91 \pm 0.94^{\mathrm{cD}}$ \\
\hline & 3 & $25.07 \pm 0.86^{\mathrm{dA}}$ & $29.59 \pm 0.72^{\mathrm{bB}}$ & $33.35 \pm 0.92^{\mathrm{cC}}$ & $34.91 \pm 0.92^{\mathrm{cD}}$ & $37.30 \pm 0.78^{\mathrm{dE}}$ \\
\hline
\end{tabular}

The results are expressed as means \pm standard deviations of triplicate determinations. Values with different letters (lower case) within a column for each solvent extract were significantly different $(p<0.05)$. Values with different letters (uppercase) within a row for each solvent extract were significantly different $(p<0.05)$.

$\mathrm{CME}$ - methanol extract, $\mathrm{CMW}-70 \%$ methanol in water extract, $\mathrm{CEE}$ - ethanol extract, $\mathrm{CEW}-70 \%$ ethanol in water extract.

Table 4. Effect of microwave pretreatment on hydroxyl radical scavenging activity of solvent extracts of black cumin seed

\begin{tabular}{ccccccc}
\hline \multirow{2}{*}{$\begin{array}{c}\text { Solvent } \\
\text { extract }\end{array}$} & $\begin{array}{c}\text { Pretreatment } \\
\text { time, min }\end{array}$ & 31.25 & 62.5 & 125 & 250 & 500 \\
\cline { 2 - 6 } & 2 & 3 & 4 & 5 & 6 & 7 \\
\hline $\mathrm{CMW}$ & 0 & $25.59 \pm 1.26^{\mathrm{aA}}$ & $30.95 \pm 0.95^{\mathrm{aB}}$ & $36.49 \pm 1.11^{\mathrm{aC}}$ & $43.00 \pm 1.13^{\mathrm{aD}}$ & $55.35 \pm 1.12^{\mathrm{aE}}$ \\
& 1 & $28.55 \pm 1.23^{\mathrm{bA}}$ & $35.12 \pm 0.79^{\mathrm{bB}}$ & $40.45 \pm 0.78^{\mathrm{bC}}$ & $54.54 \pm 1.20^{\mathrm{bD}}$ & $67.33 \pm 0.79^{\mathrm{bE}}$ \\
& 2 & $35.14 \pm 0.81^{\mathrm{cA}}$ & $40.62 \pm 1.26^{\mathrm{cB}}$ & $48.21 \pm 0.94^{\mathrm{cC}}$ & $63.22 \pm 1.11^{\mathrm{cD}}$ & $74.11 \pm 0.89^{\mathrm{cE}}$ \\
& 3 & $40.31 \pm 0.87^{\mathrm{dA}}$ & $44.57 \pm 1.00^{\mathrm{dB}}$ & $53.03 \pm 0.99^{\mathrm{dC}}$ & $66.84 \pm 1.08^{\mathrm{dD}}$ & $81.68 \pm 1.63^{\mathrm{dE}}$ \\
& 0 & $23.21 \pm 1.34^{\mathrm{aA}}$ & $25.33 \pm 1.11^{\mathrm{aB}}$ & $31.25 \pm 1.04^{\mathrm{aC}}$ & $36.12 \pm 0.65^{\mathrm{aD}}$ & $42.55 \pm 0.81^{\mathrm{aE}}$ \\
& 1 & $26.38 \pm 1.17^{\mathrm{bA}}$ & $31.45 \pm 0.80^{\mathrm{bB}}$ & $37.22 \pm 0.85^{\mathrm{bC}}$ & $50.65 \pm 1.07^{\mathrm{bD}}$ & $55.11 \pm 0.72^{\mathrm{bE}}$ \\
& 2 & $28.35 \pm 0.74^{\mathrm{bA}}$ & $38.14 \pm 0.77^{\mathrm{cB}}$ & $41.22 \pm 0.68^{\mathrm{cC}}$ & $55.54 \pm 1.28^{\mathrm{cD}}$ & $63.66 \pm 1.12^{\mathrm{cE}}$ \\
& 3 & $33.22 \pm 1.11^{\mathrm{cA}}$ & $41.23 \pm 1.19^{\mathrm{dB}}$ & $47.52 \pm 1.11^{\mathrm{dC}}$ & $60.36 \pm 0.69^{\mathrm{dD}}$ & $72.46 \pm 0.63^{\mathrm{dE}}$ \\
\hline
\end{tabular}


Hossen, J., Ali, A. (2019). Effect of microwave radiation on the antioxidant activity of black cumin seed. Acta Sci. Pol. Technol. Aliment., 18(3), 257-268. http://dx.doi.org/10.17306/J.AFS.2019.0671

Table 4 cont.

\begin{tabular}{ccccccc}
\hline 1 & 2 & 3 & 4 & 5 & 6 & 7 \\
\hline $\mathrm{CME}$ & 0 & $15.87 \pm 1.65^{\mathrm{aA}}$ & $21.74 \pm 1.50^{\mathrm{aB}}$ & $27.12 \pm 0.50^{\mathrm{aC}}$ & $34.12 \pm 0.49^{\mathrm{aD}}$ & $40.33 \pm 1.10^{\mathrm{aE}}$ \\
& 1 & $20.12 \pm 0.77^{\mathrm{bA}}$ & $25.22 \pm 0.90^{\mathrm{bB}}$ & $34.32 \pm 0.80^{\mathrm{bC}}$ & $40.55 \pm 1.67^{\mathrm{bD}}$ & $51.34 \pm 1.30^{\mathrm{bE}}$ \\
& 2 & $22.52 \pm 1.13^{\mathrm{cA}}$ & $28.65 \pm 0.91^{\mathrm{cB}}$ & $38.84 \pm 1.08^{\mathrm{cC}}$ & $45.59 \pm 1.37^{\mathrm{cD}}$ & $61.32 \pm 1.06^{\mathrm{cE}}$ \\
& 3 & $26.37 \pm 0.83^{\mathrm{dA}}$ & $35.65 \pm 1.28^{\mathrm{dB}}$ & $42.67 \pm 1.64^{\mathrm{dC}}$ & $50.58 \pm 1.46^{\mathrm{dD}}$ & $68.77 \pm 1.40^{\mathrm{dE}}$ \\
$\mathrm{CEE}$ & 0 & $13.27 \pm 1.03^{\mathrm{aA}}$ & $18.55 \pm 0.87^{\mathrm{aB}}$ & $25.64 \pm 1.23^{\mathrm{aC}}$ & $31.58 \pm 1.24^{\mathrm{aD}}$ & $41.25 \pm 1.13^{\mathrm{aE}}$ \\
& 1 & $18.54 \pm 1.32^{\mathrm{bA}}$ & $23.65 \pm 1.40^{\mathrm{bB}}$ & $33.21 \pm 0.88^{\mathrm{bC}}$ & $38.15 \pm 0.47^{\mathrm{bD}}$ & $52.16 \pm 0.62^{\mathrm{bE}}$ \\
& 2 & $21.51 \pm 1.19^{\mathrm{cA}}$ & $26.95 \pm 1.63^{\mathrm{cB}}$ & $36.86 \pm 1.12^{\mathrm{cC}}$ & $50.65 \pm 0.90^{\mathrm{cD}}$ & $58.48 \pm 0.72^{\mathrm{cE}}$ \\
& 3 & $25.18 \pm 0.61^{\mathrm{dA}}$ & $34.17 \pm 0.81^{\mathrm{dB}}$ & $40.58 \pm 0.74^{\mathrm{dC}}$ & $57.68 \pm 1.13^{\mathrm{dD}}$ & $65.77 \pm 0.79^{\mathrm{dE}}$ \\
\hline
\end{tabular}

The results are expressed as means \pm standard deviations of triplicate determinations. Values with different letters (lower case) within a column for each solvent extract were significantly different $(p<0.05)$. Values with different letters (uppercase) within a row for each solvent extract were significantly different $(p<0.05)$.

$\mathrm{CME}$ - methanol extract, $\mathrm{CMW}-70 \%$ methanol in water extract, $\mathrm{CEE}-$ ethanol extract, $\mathrm{CEW}-70 \%$ ethanol in water extract.

Table 5. Effect of microwave pretreatment on reducing power of solvent extracts of black cumin seed

\begin{tabular}{|c|c|c|c|c|c|c|}
\hline \multirow{2}{*}{$\begin{array}{l}\text { Solvent } \\
\text { extract }\end{array}$} & \multirow{2}{*}{$\begin{array}{l}\text { Pretreatment } \\
\text { time, } \min \end{array}$} & \multicolumn{5}{|c|}{ Extract concentration, $\mu \mathrm{g} / \mathrm{mL}$} \\
\hline & & 31.25 & 62.5 & 125 & 250 & 500 \\
\hline \multirow[t]{4}{*}{ CMW } & 0 & $0.26 \pm 0.005^{\mathrm{aA}}$ & $0.30 \pm 0.013^{\mathrm{aB}}$ & $0.32 \pm 0.009^{\mathrm{aC}}$ & $0.37 \pm 0.008^{\mathrm{aD}}$ & $0.41 \pm 0.009^{\mathrm{aE}}$ \\
\hline & 1 & $0.37 \pm 0.008^{\mathrm{bA}}$ & $0.40 \pm 0.007^{\mathrm{bB}}$ & $0.42 \pm 0.005^{\mathrm{bC}}$ & $0.49 \pm 0.006^{\mathrm{bD}}$ & $0.54 \pm 0.008^{\mathrm{bE}}$ \\
\hline & 2 & $0.43 \pm 0.005^{\mathrm{cA}}$ & $0.46 \pm 0.009^{\mathrm{cB}}$ & $0.52 \pm 0.008^{\mathrm{cC}}$ & $0.57 \pm 0.006^{\mathrm{cD}}$ & $0.64 \pm 0.005^{\mathrm{cE}}$ \\
\hline & 3 & $0.52 \pm 0.008^{\mathrm{dA}}$ & $0.60 \pm 0.011^{\mathrm{dB}}$ & $0.65 \pm 0.004^{\mathrm{dC}}$ & $0.66 \pm 0.010^{\mathrm{dD}}$ & $0.69 \pm 0.006^{\mathrm{dE}}$ \\
\hline \multirow[t]{4}{*}{ CEW } & 0 & $0.25 \pm 0.008^{\mathrm{aA}}$ & $0.29 \pm 0.006^{\mathrm{aB}}$ & $0.31 \pm 0.006^{\mathrm{aC}}$ & $0.36 \pm 0.007^{\mathrm{aD}}$ & $0.38 \pm 0.006^{\mathrm{aE}}$ \\
\hline & 1 & $0.29 \pm 0.006^{\mathrm{bA}}$ & $0.32 \pm 0.005^{\mathrm{bB}}$ & $0.36 \pm 0.007^{\mathrm{bC}}$ & $0.38 \pm 0.008^{\mathrm{bD}}$ & $0.42 \pm 0.006^{\mathrm{bE}}$ \\
\hline & 2 & $0.32 \pm 0.006^{\mathrm{cA}}$ & $0.42 \pm 0.005^{\mathrm{cB}}$ & $0.45 \pm 0.007^{\mathrm{cC}}$ & $0.46 \pm 0.006^{\mathrm{cD}}$ & $0.50 \pm 0.006^{\mathrm{cE}}$ \\
\hline & 3 & $0.37 \pm 0.004^{\mathrm{dA}}$ & $0.48 \pm 0.006^{\mathrm{dB}}$ & $0.48 \pm 0.005^{\mathrm{dC}}$ & $0.51 \pm 0.008^{\mathrm{dD}}$ & $0.56 \pm 0.011^{\mathrm{dE}}$ \\
\hline \multirow[t]{4}{*}{ CME } & 0 & $0.22 \pm 0.007^{\mathrm{aA}}$ & $0.24 \pm 0.008^{\mathrm{aB}}$ & $0.29 \pm 0.007^{\mathrm{aC}}$ & $0.31 \pm 0.003^{\mathrm{aD}}$ & $0.34 \pm 0.005^{\mathrm{aE}}$ \\
\hline & 1 & $0.24 \pm 0.006^{\mathrm{bA}}$ & $0.27 \pm 0.004^{\mathrm{bB}}$ & $0.31 \pm .0004^{\mathrm{bC}}$ & $0.36 \pm 0.007^{\mathrm{bD}}$ & $0.40 \pm 0.005^{\mathrm{bE}}$ \\
\hline & 2 & $0.31 \pm 0.008^{\mathrm{cA}}$ & $0.36 \pm 0.013^{\mathrm{cB}}$ & $0.39 \pm 0.005^{\mathrm{cC}}$ & $0.41 \pm 0.004^{\mathrm{cD}}$ & $0.48 \pm 0.007^{\mathrm{cE}}$ \\
\hline & 3 & $0.36 \pm 0.009^{\mathrm{dA}}$ & $0.41 \pm 0.005^{\mathrm{dB}}$ & $0.48 \pm 0.007^{\mathrm{dC}}$ & $0.50 \pm 0.008^{\mathrm{dC}}$ & $0.56 \pm 0.005^{\mathrm{dD}}$ \\
\hline \multirow[t]{4}{*}{ CEE } & 0 & $0.21 \pm 0.008^{\mathrm{aA}}$ & $0.23 \pm 0.008^{\mathrm{aB}}$ & $0.27 \pm 0.007^{\mathrm{aC}}$ & $0.29 \pm 0.003^{\mathrm{aD}}$ & $0.32 \pm 0.007^{\mathrm{aE}}$ \\
\hline & 1 & $0.23 \pm 0.006^{\mathrm{bA}}$ & $0.25 \pm 0.004^{\mathrm{bB}}$ & $0.29 \pm 0.007^{\mathrm{bC}}$ & $0.32 \pm 0.004^{\mathrm{bD}}$ & $0.35 \pm 0.007^{\mathrm{bE}}$ \\
\hline & 2 & $0.27 \pm 0.006^{\mathrm{cA}}$ & $0.31 \pm 0.006^{\mathrm{cB}}$ & $0.34 \pm 0.006^{\mathrm{cC}}$ & $0.35 \pm 0.007^{\mathrm{cD}}$ & $0.39 \pm 0.005^{\mathrm{cE}}$ \\
\hline & 3 & $0.32 \pm 0.005^{\mathrm{dA}}$ & $0.34 \pm 0.008^{\mathrm{dB}}$ & $0.36 \pm 0.006^{\mathrm{dC}}$ & $0.38 \pm 0.007^{\mathrm{dD}}$ & $0.40 \pm 0.004^{\mathrm{dE}}$ \\
\hline
\end{tabular}

The results are expressed as means \pm standard deviations of triplicate determinations. Values with different letters (lower case) within a column for each solvent extract were significantly different $(p<0.05)$. Values with different letters (uppercase) within a row for each solvent extract were significantly different $(p<0.05)$.

$\mathrm{CME}-$ methanol extract, $\mathrm{CMW}-70 \%$ methanol in water extract, $\mathrm{CEE}-$ ethanol extract, $\mathrm{CEW}-70 \%$ ethanol in water extract. 
atom and preventing peroxide formation (Sharma et al., 2012). As shown in Table 5, the pretreatment of sample significantly $(p<0.05)$ increased the reducing power that might be attributed to the production of Maillard reaction products contributing to the antioxidant capacity after treatment. Wani et al. (2016) also concluded that microwave roasting increased the reducing power of extracts from arrowhead. The present data also revealed that reducing power was dose-dependent and increasing the concentration of extract led to a significant increase in reducing power in native and pretreated samples. Zhao et al. (2014) also found that the reducing power increased with
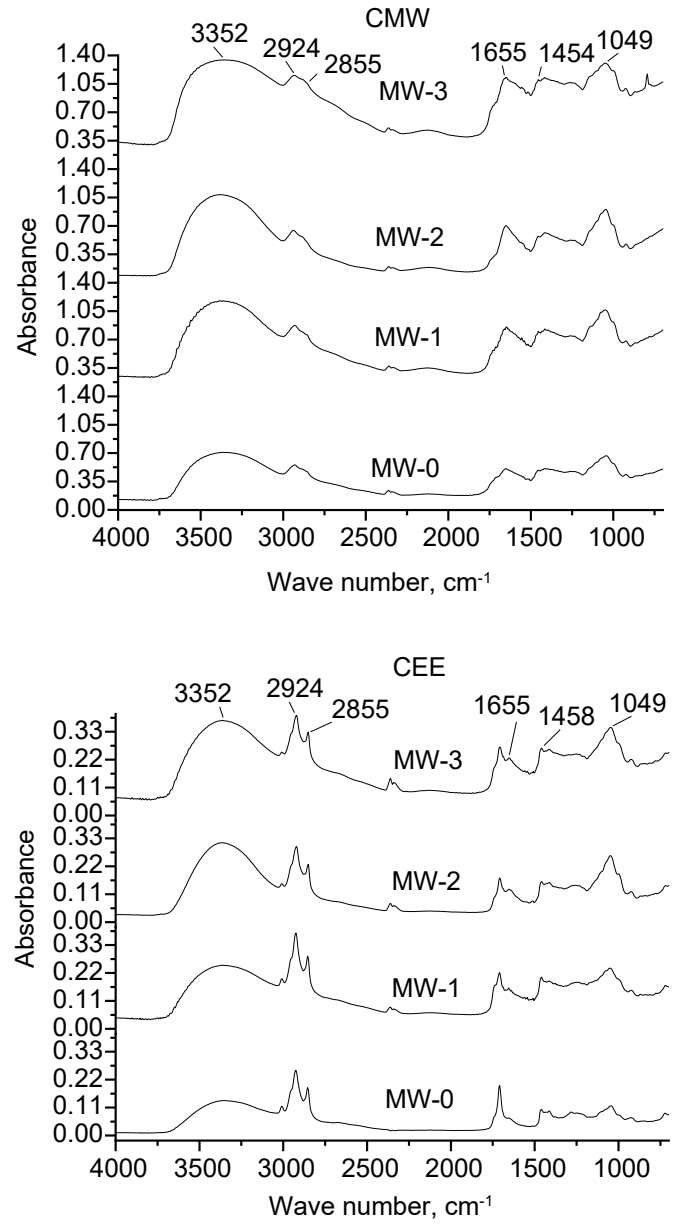

increasing extract concentrations of some common legumes. The reducing power as an absorbance value of raw and pretreated cumin seeds at a concentration of $500 \mu \mathrm{g} / \mathrm{mL}$ ranged from 0.41 to 0.69 (CMW), 0.38 to 0.56 (CEW), 0.34 to 0.56 (CME), and 0.32 to 0.40 (CEE). The average values of reducing power varied significantly among different solvents both in native as well as treated seeds.

\section{Evaluation by FT-IR}

To predict antioxidant activities of seed extracts, FT-IR spectral features were studied and presented in Figure 1 . The distinctive bands reflecting the information

Fig. 1. FT-IR spectra of solvent extracts CMW, CEW, CME and CEE of black cumin seeds: MW-0 - pretreated at 0 min, MW- 1 - pretreated at $1 \mathrm{~min}, \mathrm{MW}-2$ - pretreated at $2 \mathrm{~min}, \mathrm{MW}-3$ - pretreated at $3 \mathrm{~min}$; $\mathrm{CME}$ - methanol extract, $\mathrm{CMW}-70 \%$ methanol in water extract, $\mathrm{CEE}$ - ethanol extract, $\mathrm{CEW}-70 \%$ ethanol in water extract 
about the structure of polyphenols were found in the regions 3390-3352 $\mathrm{cm}^{-1}$ (attributed to the stretch of $\mathrm{O}-\mathrm{H}$ ) and $1049 \mathrm{~cm}^{-1}$ (attributed to $\mathrm{C}-\mathrm{H}$ stretch) (Batista et al., 2016) and recognized in all the solvent extracts. The hydroxyl functionality is an integral part of most phenolic phytochemicals, such as polyphenols and flavonoids, to provide a relative ranking of extracts in terms of antioxidant activity. The bands at $2924-2854 \mathrm{~cm}^{-1}$ (attributed to the stretch of the C-H of aromatic ring) assigned to the aromatic ring (Batista et al., 2016) were found in all extracts. The sharp absorption peak at frequency $1739 \mathrm{~cm}^{-1}$ was assigned to $-\mathrm{C}=\mathrm{O}$ stretching vibration in carbonyl compounds, which may be characterized by the presence of high polyphenol content in the samples (Kiat et al., 2014). All the seed extracts have aromatic domain bands at a frequency of $1654 \mathrm{~cm}^{-1}$ (attributed to C-C stretch of aromatic ring) due to phenolics present in the sample (Batista et al., 2016) and a weak band at frequency of $1458 \mathrm{~cm}^{-1}$ due to carboxylic C-O band of polyphenols (Kiat et al., 2014). The FT-IR spectra of the seeds showed similar spectral characteristics of the functional group region, which indicates similar components of the samples. The presence and distribution of these functional groups on the chemical structures of polyphenols may influence their antioxidant properties in fruits as well as their bioavailability. The absorbance difference of different samples (raw or treated) suggested the unequal levels of phenolic content in the solvent extracts. Of course, in most case, the intensities of bands increased with pretreatment time. This observation clearly shows that pretreatment of seeds effectively influences the phenolic content and antioxidant activity.

\section{CONCLUSIONS}

The microwave radiation has been found to significantly improve the antioxidant activities including free radical scavenging against DPPH and hydroxyl radicals. The present data also revealed that the antioxidant power of various extracts was dose-dependent and increasing the extract concentration led to a significant $(p<0.05)$ increase in the antioxidant power. In particular, the black cumin seeds microwaved for 3 min and at a dose of $500 \mu \mathrm{g} / \mathrm{mL}$ presented higher antioxidant activity than those treated for 1 or 2 mins and other concentrations. Aqueous methanol extract from microwaved seeds was found to be a potent source of antioxidant agents in comparison to other solvent extracts. The present findings also indicate that although microwave processing decreased the flavonoid contents in cumin seeds with a prolongation of treatment time, the F-C-reducing capacity and radical-scavenging activities are preserved. This study is important to determine optimum microwave processing conditions in order to maximize the anti-oxidative health benefits of cumin seeds.

\section{REFERENCES}

Adom, K. K., Mark, E., Sorrells, A., Liu, R. H. (2005). Phytochemicals and antioxidant activity of milled fractions of different wheat varieties. J. Agric. Food Chem., 53, 2297-2306. http://dx.doi.org/10.1021/jf048456d

Ali, A., Islam, A., Pal, T. K. (2016). The effect of microwave roasting on the antioxidant properties of the Bangladeshi groundnut cultivar. Acta Sci. Pol. Technol. Aliment., 15, 429-438. http://dx.doi.org/10.17306/J.AFS.2016.4.41

Ali, M. A., Nargis, A., Othman, N. H., Noor, A. F., Sadik, G., Hossen, J. (2017). Oxidation stability and compositional characteristics of oils from microwave roasted pumpkin seeds during thermal oxidation. Int. J. Food Prop., 20, 2569-2580. http://dx.doi.org/10.1080/10942 912.2016.1244544

AOAC (2005). Official methods of analysis of AOAC International. VA, USA: AOAC International.

Atmani, D., Chaher, N., Berboucha, M., Ayouni, K., Lounis, H., Boudaoud, H., ..., Atmani, D. (2009). Antioxidant capacity and phenol content of selected Algerian medicinal plants. Food Chem., 112, 303-309. http://dx.doi. org/10.1016/j.foodchem.2008.05.077

Atta, M. B. (2003). Some characteristics of nigella (Nigella sativa L.) seed cultivated in Egypt and its lipid profile. Food Chem., 83, 63-68. http://dx.doi.org/10.1016/ S0308-8146(03)00038-4

Baba, W. B., Rashid, I., Shah, A., Ahmad, M., Gani, A., Masoodi, F. A., ..., Wani, S. M. (2016). Effect of microwave roasting on antioxidant and anticancerous activities of barley flour. J. Saudi Soc. Agric. Sci., 15, 12-19. http://dx.doi.org/10.1016/j.jssas.2014.06.003

Batista, N. N, de Andrade, D. P., Ramos, C. L., Dias, D. R., Schwan, R. F. (2016). Antioxidant capacity of cocoa beans and chocolate assessed by FTIR. Food Res. Int., 90, 313-319. http://dx.doi.org/10.1016/j. foodres.2016.10.028 
Đurđević, S., Milovanović, S., Šavikin, K., Ristić, M., Menković, N., Pljevljakušić, D., ..., Bogdanović, A. (2017). Improvement of supercritical $\mathrm{CO}_{2}$ and $n$-hexane extraction of wild growing pomegranate seed oil by microwave pretreatment. Ind. Crops Prod., 104, 21-27. http://dx.doi.org/10.1016\%2Fj.indcrop.2017.04.024

Forouzanfar, F., Bazzaz, B. S. F., Hosseinzadeh, H. (2014). Black cumin (Nigella sativa) and its constituent (thymoquinone): A review on antimicrobial effects. Iran. J. Basic Med. Sci., 17, 929-938.

Guo, T., Wei, L., Sun, J., Hou, C., Fan, L. (2011). Antioxidant activities of extract and fractions from Tuber indicum Cooke \& Massee. Food Chem., 127, 1634-1640. http://dx.doi.org/10.1016/j.foodchem.2011.02.030

Imlay, J. A., Linn, S. (1988). DNA damage and oxygen radical toxicity. Science, 240, 1302-1309. https://doi. org/10.1126/science. 3287616

Ito, N., Hirose, M., Fukushima, S., Tsuda, H., Shirai, T., Tatematsu, M. (1986). Studies on antioxidants: Their carcinogenic and modifying effects on chemical carcinogens. Food Chem. Toxicol., 24, 1071-1082. http://dx.doi. org/10.1016/0278-6915(86)90291-7

Jan, K., Ahmad, M., Rehman, S., Gani, A., Khaqan, K. (2019). Effect of roasting on physicochemical and antioxidant properties of kalonji (Nigella sativa) seed flour. J. Food Meas. Charact., 13, 1364-1372. http://dx.doi. org/10.1007/s11694-019-00052-4

Juntachote, T., Berghofer, E. (2005). Antioxidative properties and stability of ethanolic extracts of Holy basil and Galangal. Food Chem., 92, 193-202. http://dx.doi. org/10.1016/j.foodchem.2004.04.044

Kadam, D., Shah, N., Palamthodi, S., Lele, S. S. (2018). An investigation on the effect of polyphenolic extracts of Nigella sativa seedcake on physicochemical properties of chitosan-based films. Carbohydr. Polym., 192, 347355. http://dx.doi.org/10.1016/j.carbpol.2018.03.052

Kiat, V. V., Siang, W. K., Madhavan, P., Chin, J. H., Ahmad, M., Akowuah, G. A. (2014). FT-IR profile and antiradical activity of dehulled kernels of apricot, almond and pumpkin. Res. J. Pharm. Biol. Chem. Sci., 5, 112-120.

Kiralan, M. (2012). Volatile compounds of black cumin seeds (Nigella sativa L.) from microwave-heating and conventional roasting. J. Food Sci., 77, C481-C484. http://dx.doi.org/10.1111/j.1750-3841.2012.02638.x

Negro, C., Tommasi, L., Miceli, A. (2003). Phenolic compounds and antioxidant activity from red grape marc extracts. Bioresour. Technol., 87, 41-44. http://dx.doi. org/10.1016/S0960-8524(02)00202-X

Pandey, H., Awasthi, P. (2015). Effect of processing techniques on nutritional composition and antioxidant activity of fenugreek (Trigonella foenum-graecum) seed flour. J. Food Sci. Technol., 52, 1054-1060. http:// dx.doi.org/10.1007/s13197-013-1057-0

Ruch, R. J., Cheng, S. J., Klaunig, J. E. (1989). Prevention of cytotoxicity and inhibition of intercellular communication by antioxidant catechins isolated from Chinese green tea. Carcinogenesis, 10, 1003-1008. http://dx.doi. org/10.1093/carcin/10.6.1003

Saito, M., Sakagami, H., Fujisawa, S. (2002). Cytotoxicity and apoptosis induction by butylated hydroxyanisole (BHA) and butylated hydroxytoluene (BHT). Anticancer Res., 23, 4693-4701.

Sasipriya, G., Siddhuraju, P. (2012). Effect of different processing methods on antioxidant activity of underutilized legumes, Entada scandens seed kernel and Canavalia gladiata seeds. Food Chem. Toxicol., 50, 2864-2872. http://dx.doi.org/10.1016/j.fct.2012.05.048

Saxena, S. N., Rathore, S. S., Diwakar, Y., Kakani, R. K., Kant, K., Dubey, P. N., ..., John, S. (2017). Genetic diversity in fatty acid composition and antioxidant capacity of Nigella sativa L. genotypes. LWT - Food Sci. Technol., 78, 198-207. http://dx.doi.org/10.1016/j. lwt.2016.12.033

Sharma, A., Gur, R., Bhalla, P. (2012). Kuppuswamy's socioeconomic scale: updating income ranges for the year 2012. Indian J. Public Health, 56, 103-104. http:// dx.doi.org/10.4103/0019-557X.96988

Škerget, M., Kotnik, P., Hadolin, M., Hraš, A. R., Simonič, M., Knez, Ž. (2005). Phenols, proanthocyanidins, flavones and flavonols in some plant materials and their antioxidant activities. Food Chem., 89, 191-198. http:// dx.doi.org/10.1016/j.foodchem.2004.02.025

Smirnoff, N., Cumbes, Q. J. (1989). Hydroxyl radical scavenging activity of compatible solutes. Phytochem., 28, 1057-1060. http://dx.doi.org/10.1016/00319422(89)80182-7

Soleimanifar, M., Niazmand, R., Jafari, S. M. (2019). Evaluation of oxidative stability, fatty acid profile, and antioxidant properties of black cumin seed oil and extract. J. Food Meas. Charact., 13, 383-389. http://dx.doi. org/10.1007/s11694-018-9953-7

Wani, I. A., Gani, A., Tariq, A., Sharma, P., Masoodi, F. A., Wani, H. M. (2016). Effect of roasting on physicochemical, functional and antioxidant properties of arrowhead (Sagittaria sagittifolia L.) flour. Food Chem., 197, 345352. http://dx.doi.org/10.1016/j.foodchem.2015.10.125

Wu, S. J., Ng, L. T. (2008). Antioxidant and free radical scavenging activities of wild bitter melon (Momordica charantia Linn. var. abbreviata Ser.) in Taiwan. 
Hossen, J., Ali, A. (2019). Effect of microwave radiation on the antioxidant activity of black cumin seed. Acta Sci. Pol. Technol. Aliment., 18(3), 257-268. http://dx.doi.org/10.17306/J.AFS.2019.0671

LWT - Food Sci. Technol., 41, 323-330. http://dx.doi. org/10.1016/j.lwt.2007.03.003

Yassari, S., Yasari, E. (2013). Effects of extract of Thompson orange peels on the stability of canola oil. Int. J. Agric. Crop. Sci., 5, 450-454.
Zhao, Y., Du, S., Wang, H., Cai, M. (2014). In vitro antioxidant activity of extracts from common legumes. Food Chem., 152, 462-466. http://dx.doi.org/10.1016/j.foodchem.2013.12.006 